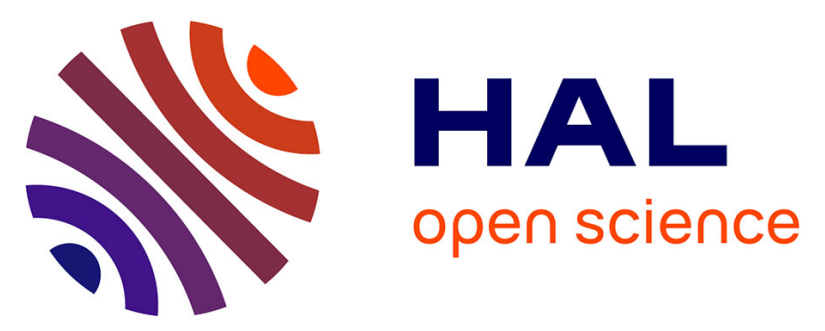

\title{
STRUCTURAL CHANGES ORIGINATING IN THE BLANK MATERIAL AT THE MOMENT OF COLLISION WITH TOOLING AND THEIR INFLUENCE ON THE QUALITY OF THE FINISHED WORKPIECE
}

V. Glouschenkov, V. Grechnikov

\section{To cite this version:}

V. Glouschenkov, V. Grechnikov. STRUCTURAL CHANGES ORIGINATING IN THE BLANK MATERIAL AT THE MOMENT OF COLLISION WITH TOOLING AND THEIR INFLUENCE ON THE QUALITY OF THE FINISHED WORKPIECE. Journal de Physique IV Proceedings, 1991, 01 (C3), pp.C3-335-C3-339. 10.1051/.jp4:1991348 . jpa-00250492

HAL Id: jpa-00250492 https://hal.science/jpa-00250492

Submitted on 1 Jan 1991

HAL is a multi-disciplinary open access archive for the deposit and dissemination of scientific research documents, whether they are published or not. The documents may come from teaching and research institutions in France or abroad, or from public or private research centers.
L'archive ouverte pluridisciplinaire HAL, est destinée au dépôt et à la diffusion de documents scientifiques de niveau recherche, publiés ou non, émanant des établissements d'enseignement et de recherche français ou étrangers, des laboratoires publics ou privés. 
STRUCTURAL CHANGES ORIGINATING IN THE BLANK MATERIAL AT THE MOMENT OF COLLISION WITH TOOLING AND THEIR INFLUENCE ON THE QUALITY OF THE FINISHED WORKPIECE

\author{
V. GLOUSCHENKOV and V. GRECHNIKOV \\ 34. Moskouskoye Shosse, Kuibyshev Aviation Institute, \\ Samara, 443086, USSR
}

Résumé: Cette étude considère les conditions pour générer les changements de structure et leur influence sur le degré de déformation d'un tube avant la collision, sur la vitesse de collision et sur les propriétés physiques et mécaniques du matériau impacté. Les limites supérieures et inféricures pour la vitesse de collision qui permettent de déterminer les changements de structure ont été fixćes. On montre l'influence de la vitesse sur la valeur des contraintes résiduelles et les dimensions finales de la pièce.

\begin{abstract}
The paper considers the conditions of generating structural changes and their dependence on the degree of tangential stmuctural strain of a blank before the collision, on the collision velocity and on the mechanical and physical properties of the colliding materials. Lower and upper boundaries for the collision velocities determining structural changes are set. The velocities influence upon the value of residual stresses and upon the workpiece final dimensions is shown.
\end{abstract}

\begin{abstract}
Products of different branches of machine building include hollow members. There exist various technological processes of such members manufacturing and among them impulse and magnetic-pulse techniques are widely adopted /1/.

Under the pressure of an impulse magnetic fielda blank shaping is performed, the process resulting in a blank impingement against a die. By the moment of collision the blank has been deformed to the degree $\varepsilon_{\varphi}=\ln D_{k} / D_{0}$ and has acquired the velocity $V_{C}$ (Fig.1).
\end{abstract}




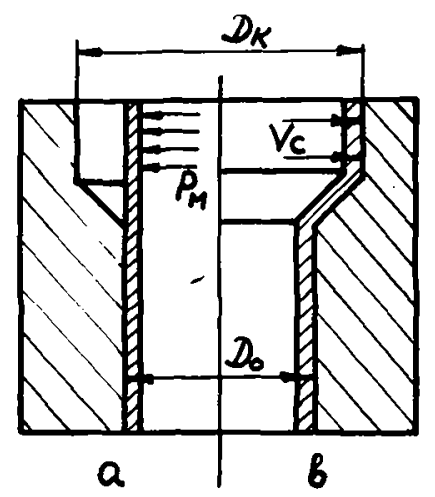

Fig. 1. The scheme of masnetic-pulse stamping of an adapter:

a) initial position;

b) final position.

The speed of collision in this process influences the final workpiece dimensions (Fig.2).

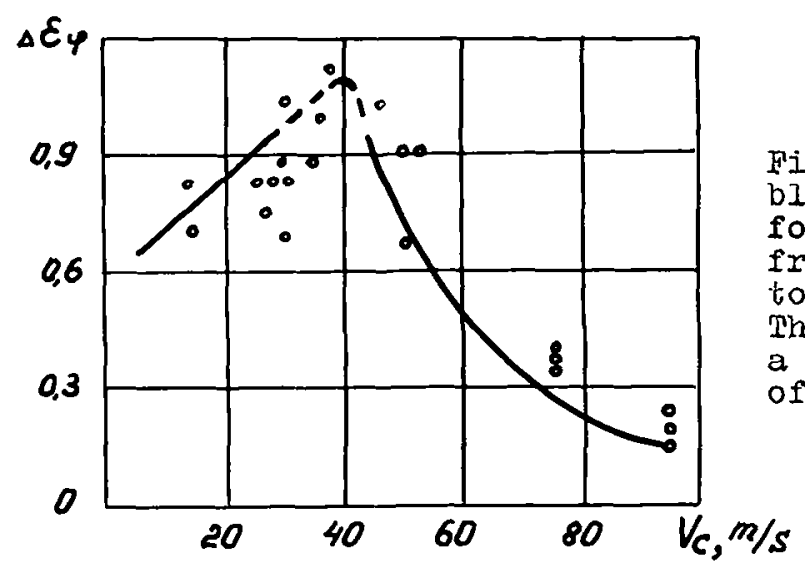

Collision may be either elastic one when despite plastic deformation of the blank it induces only elastic waves of strain and deformation through its thickness or plasto-elastic one when both elastic and plastic waves of strain and deformation propagate along plastically stretched blani (Fig.3) /2/.

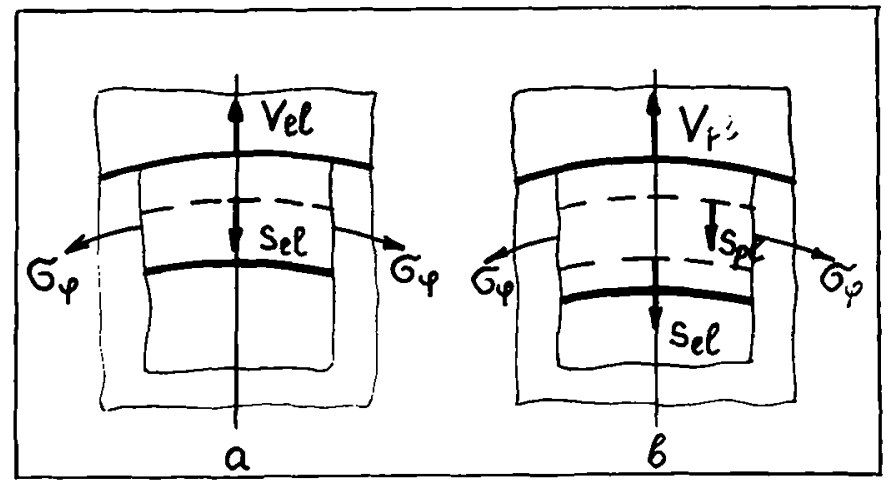

Fig.3. The scheme of strain and deformation wave propagation under elastic collisions (a) and plasto-elastic collisions (b). Respectively $\left.S_{e}\right]$ and $S_{p l}$ are speeds of elastic and plastic wave propagation. 
Under plasto-elastic collision some structural changes are observed at the depth of plastic wave propagation. So, AnG6il alloy structures being obtained as a result of plastic form-changing up to $\varepsilon_{y}=5 \%$ illustrate possibilities of plastic and plasto-elastic collisions. When the collision velocity is $V_{c}=30 \mathrm{~m} / \mathrm{sec}$ the structure of the material remains uniform and bears no changes generated by the impingement. The structure of workpiece material experiencing collision velocity of $V_{C}=50 \mathrm{~m} / \mathrm{sec}$ has two typical zones: a zone with a strong plastic deformation of the impinged surface and a zone with a slight defornation. Etched microsection metallographic specimens were subjected to microstmctural investigation by means of MUL-8W microscope. The depth of plastic wave propagation depends upon the conditions of interaction between direct strain and deformation waves and waves reflected by the free surface.

Stmctural changes result in changes of residual stress level $\sigma_{\text {res }}$ through the blank thickness /3/. Professor Birger's method was used as a basis for determining residual stresses. Fig. 4 shows an example of the relation $\sigma_{r e s}=f\left(V_{c}\right)$, where $\mathcal{E}_{p}$ equals 1.25 (for outer fibres of the finished workpiece). As the figure shows the relation contains three typical zones. Within the first one the residual stress amplitude does not depend on the collision velocity. Further on $\sigma_{\text {res }}$ is increasing (zone 2). Under the collision velocities more than $V_{C}=110 \mathrm{~m} / \mathrm{sec}$ this relation remains straight but the angle of its slope to the abscissa axig changes (zone 3 ).

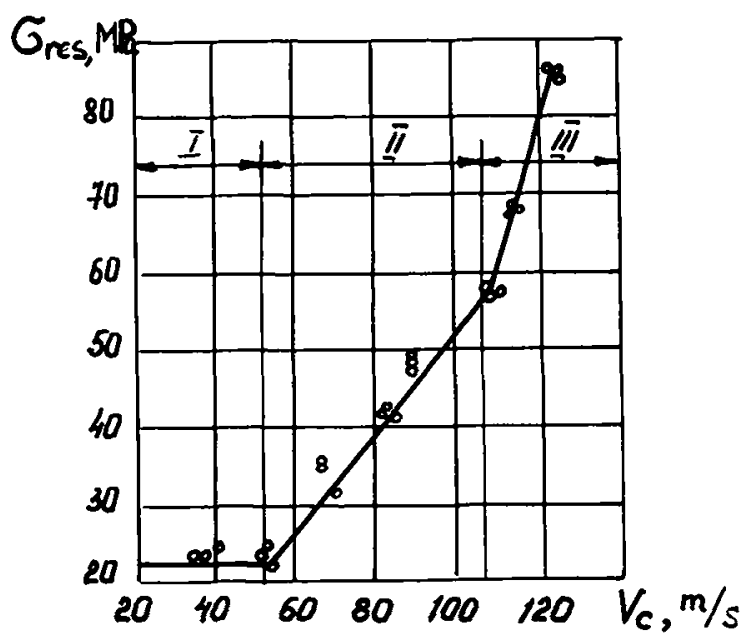

Fig.4. Relation between residual stresses $G_{\text {res }}$ and collision velocity $V_{c}$. 
The die stability and its possible plastic deformation set a limit on the ultimate collision velocity Vult (Fig.5).

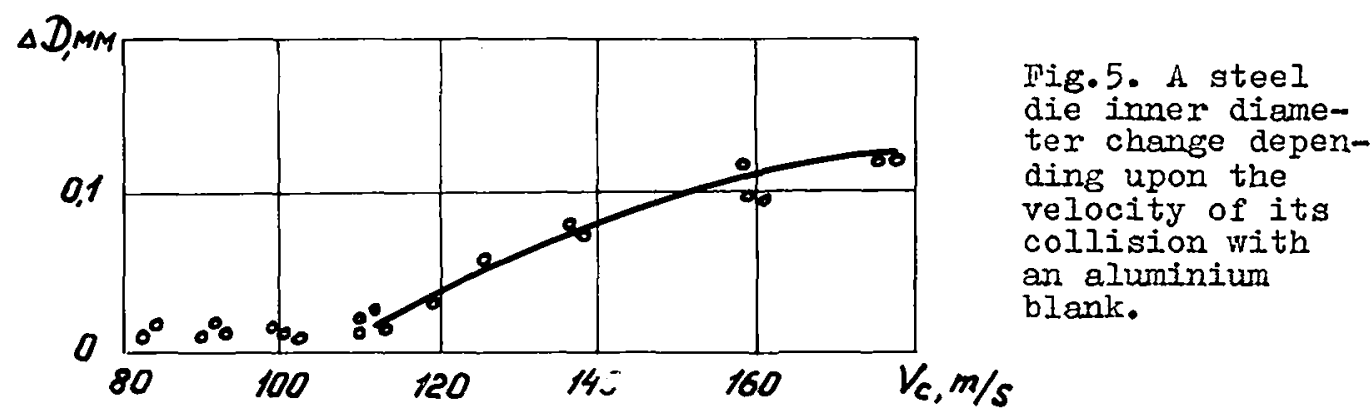

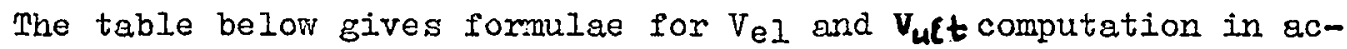
cordance with the mechanical properties of the colliding materials, their acoustic stiffness $\rho S$ and $\mathcal{E}_{\varphi}$ value at the moment of collision, the data being obtained for short blanks.

Under the collision velocity $V_{c}<V_{e}-c o l l i s i o n$ is elastic, under the velocity $V_{e l}<V_{c}<V_{u l t}$ collision is plastomelastic. For an aluminiun AMg6n blank and a steel st45 die when $\varepsilon_{\varphi}=1.25$ these vaIues are as follows: $V_{e l}=44.5 \mathrm{~m} / \mathrm{sec}, V_{\text {utt }}=130 \mathrm{~m} / \mathrm{sec}$.

Table

\begin{tabular}{ll}
$\begin{array}{l}\text { Ultimate } \\
\text { colizion } \\
\text { velocity }\end{array}$ & $V_{u l t}=\left(\frac{\sigma_{a, 2}}{\rho S_{l l}} \cdot \frac{1-\nu}{1-2 \nu}\right)^{\text {die }} \cdot\left[1+\frac{\left(\rho S_{l l}\right)^{\text {die }}}{\left(\rho S_{e l}\right)^{b l}}\right]$ \\
$\begin{array}{l}\text { Ultimate } \\
\text { elastic collision } \\
\text { velocity }\end{array}$ & $V_{l l}=\frac{2}{\sqrt{3}} \cdot k \varepsilon_{\varphi}^{n} \frac{\left(\rho S_{l} l\right)^{\text {die }}+\left(\rho S_{e l}\right)^{b l}}{\left(\rho S_{l l}\right)^{\text {die }}\left(\rho S_{l l}\right)^{b l}}$ \\
\hline
\end{tabular}

Thus, for developing technological processes for impulse shaping of hollow workpieces it is necessary to consider the collision velocity, level and distribution of residual stresses and the final dimensions of the workpiece. 


\section{References}

I. Глущенков В.А. Црименение импульсных магнитных полей в технологии листовой штамповки / Кузнечно-штамповочное производство.-1985.-\$6 8.-C.I8-2I

2. Глущенков В.А., Комаров А.Д., Щеглов Б.А. Упругое соударение цилиндрической заготовки С матрицей при магнитно-имтульсной обработке металлов / Машиноведение.1972.- 3. - - . 106-113

3. Колпвшников А.И., Козий С.И., Глущенков В.А. Влияние высокоскоростного соударения на величину остаточных напряжений при пластическом формоизменении /Кузнечноштамповочное проивводство.-I973. - 8. - - . I6-I8 